\title{
Publisher Correction to: Bacteria from Antarctic environments: diversity and detection of antimicrobial, antiproliferative, and antiparasitic activities
}

\author{
Tiago R. Silva ${ }^{1,2}$ - Alysson W. F. Duarte ${ }^{3} \cdot$ Michel R. Z. Passarini $^{4} \cdot$ Ana Lucia T. G. Ruiz $^{5} \cdot$ Caio Haddad Franco $^{7}$.

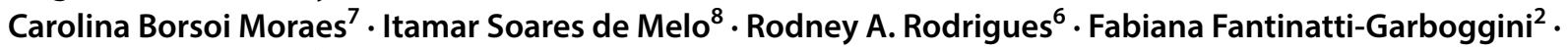 \\ Valéria Maia Oliveira²
}

Published online: 19 April 2018

(c) Springer-Verlag GmbH Germany, part of Springer Nature 2018

\section{Correction to: Polar Biol https://doi.org/10.1007/s00300-018-2300-y}

During initial stage of copyediting, extra columns were spanned in Table 2; i.e., 6 and 7 and 10 and 11 resulting from automation. This produced an extra space between columns, which went unnoticed following the proofing stage. There was no request for a correction until publication. The publisher sincerely apologizes to the authors for the inconvenience caused. The original article has been corrected.
The original article can be found online at https://doi.org/10.1007/ s00300-018-2300-y.

\section{Valéria Maia Oliveira}

vmaia@cpqba.unicamp.br

Tiago R. Silva

tiago04@gmail.com

1 Institute of Biology, Campinas State University, P.O.Box: 6109, Campinas, SP, Brazil

2 Division of Microbial Resources, Chemical, Biological and Agricultural Pluridisciplinary Research Center (CPQBA), Campinas State University, Campinas, Brazil

3 Federal University of Alagoas (UFAL), Alagoas, Brazil

4 Federal University for Latin American Integration, Foz do Iguaçu, Brazil
5 Division of Pharmacology and Toxicology, Chemical, Biological and Agricultural Pluridisciplinary Research Center (CPQBA), Campinas State University, Campinas, Brazil

6 Division of Natural Products Chemistry, Chemical, Biological and Agricultural Pluridisciplinary Research Center (CPQBA), Campinas State University, Campinas, Brazil

7 Brazilian Biosciences National Laboratory, National Center for Research IN Energy and Materials (CNPEM), Campinas, Brazil

8 Environmental Microbiology Laboratory (EMBRAPA), Jaguariuna, Brazil 